VAKANÜVis- Uluslararası Tarih Araştırmaları Dergisi/ International Journal of Historical Researches, Yıl/Vol. 1, Sayı/No. 2 Güz/Fall 2016 ISSN: 2149-9535

\title{
Sultan Hüseyin Baykara'nın Timurlu Devleti Tahtına Çıkmasından Sonra Timurlu Soyundan Bazı Mirzalar ile Giriştiği Mücadeleler
}

\section{Cihan Oruç*}

\section{Özet}

Timurlu hükümdarı Sultan Ebu Said Han'ın vefatından sonra Mirza Hüseyin Baykara, Herat'ta tahta çıktı. Baykara, tahta çıktıktan sonra Horasan ve Harezm bölgesini kendi kontrolünde tutmaya çalıştı. $O$, bir taraftan da Ebu Said Han'ın vefatı sonrasında daha önceden kendilerine verilmiş olan topraklarda mahalli hanedanlıklar olarak bağımsız hareket eden diğer Timurlu mirzalarıyla mücadele içerisinde oldu. Bu çalışmada Sultan Ebu Said Han'ın vefatı sonrasında Mirza Hüseyin Baykara'nın diğer Timurlu mirzalarıyla olan mücadeleleri anlatılacaktır.

Anahtar Kelimeler: Sultan Hüseyin Baykara, Yadigâr Muhammed, Mahmud Mirza, Ömer Mirza, Ebubekir Mirza, Mesud Mirza.

\section{Sultan Husein Bayqara's Struggles With Some Timurid Mirzas After His Accession to the Throne}

\begin{abstract}
Afterthedeath of Timurid ruler Sultan Abu Said Khan, Mirza Husain Baiqara ascended the throne in Herat. Baiqara, after coming the throne he tried to call all the shots in the area of Khorasan and Khwarezm. In the mean time he took part in the struggle with other Timurid mirzas who act independently as a local dynasties in the land given to them previously after the death of Abu Said Khan. In this study, the struggles of Mirza Hussein Baykara with other Timurid mirzas after the death of Sultan Abu Said Khan will be discussed.
\end{abstract}

Keywords: Sultan Husain Baiqara, Yadgar Muhammad, Mahmud Mirza, Umar Mirza, Ababakr Mirza, Masud Mirza.

Doktora Öğrencisi, Sakarya Üniversitesi Sosyal Bilimler Enstitüsü, Tarih Anabilim Dalı, cihansan87@gmail.com. (Makale Gönderim Tarihi: 01.07.2016, Makale Kabul Tarihi: 08.10.2016)

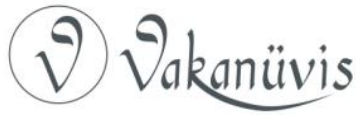




\section{Giriş}

Timurlu hükümdarı Ebu Said Sultan ${ }^{1}, 1469$ yılında Akkoyunlu hükümdarı Uzun Hasan ile giriştiği mücadelede hayatını kaybetmişti. ${ }^{2}$ Ebu Said, Şahruh gibi Timur soyunun diğer kollarından olan mirzaların elinde bulunan bütün vilayetleri ele geçirmiş veya isyanlar nedeniyle almak zorunda kalmıştı. Birçok vilayetin başına da oğullarını geçirmişti. Semerkand'da Sultan Ahmed Mirza; Herat'ta Sultan Halil Mirza; Bedehşan'da Ebubekir Mirza; Fergana'da Ömer Şeyh Mirza; Kabil'de Uluğ Bey Mirza; Kandahar ve Germsir'de Murad Mirza; Astarabad'da Sultan Mahmud Mirza hüküm sürmekteydi. Ebu Said Sultan'ın oğullarından Sultan Ahmed, Sultan Mahmud ve Ömer Şeyh Mirza babalarının yardımıyla Moğollara "Han" olan Yunus Han'ın damatlarıdır. Bu esnada Ömer Şeyh kolundan olan Hüseyin Baykara, Ebu Said ile daha önce giriştiği mücadeleden sonra Deşt-i Kıpçağ'a çekilmişti. Şahruh kolundan Yadigâr Muhammed Mirza ise Uzun Hasan'ın yanında bulunmaktaydı. Ebu Said vefat edince onun oğulları devletin birliğini korumak ve babalarının öcünü almak için herhangi bir çaba göstermedi. Kısacası Ebu Said Han'ın vefatıyla kendilerine miras kalan devletin birliğini korumak fikri ortadan kalkmış veya asıl amaç olmaktan çıkmıştır. ${ }^{3}$

Sultan Ebu Said ile çeşitli mücadelelere girmiş olan Hüseyin Baykara, onun vefatından haberdar olunca kaçtığı Deşt-i Kıpçak'tan gelerek Abıverd, Merv, Nişabur ve Meşhed'e ilerledi. Hüseyin Baykara'nın adamları Karabağ'dan gelmekte olan Ebu Said'in oğlu Sultan Mahmud Mirza'yı bozguna uğrattı. Sultan Mahmud Mirza, bu mağlubiyet sonrasında Herat'a kaçtı. Şehzade burada babası Sultan Ebu Said'in vefatını öğrendi ve buradaki ahalinin çoğunun Baykara'yı desteklediği haberini aldı. Mahmud Mirza, Andhoy'da bulunan kardeşi Sultan Ahmed Mirza'nın yanına gitti. O Herat'taki vaziyeti kardeşine

\footnotetext{
${ }^{1}$ Ebu Said Sultan dönemi hakkında ayrıntılı bilgi içim bkz: Hayrunnisa Alan, Sultan Ebu Said Devri Timurlu Tarihi (1451-1469), Basılmamış Doktora Tezi, İstanbul 1996.

2 Jean Paul Roux, Orta Asya Tarih ve Uygarlık, Çev: Lale Arslan, İstanbul 2006, s. 347.

${ }^{3}$ Gazi Zahireddin Muhammed Babur, Baburnâme, Çev: Prof. Dr. Reşit Rahmeti Arat, İstanbul 2005, s. 62.
}

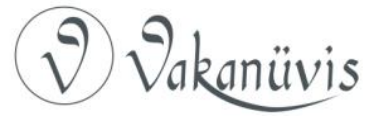


anlattıktan sonra iki kardeş Horasan'ı terk ettiler. Onlar Ceyhun'a ilerlediler ve sonra da Semerkand'a yöneldiler. ${ }^{4}$ Hüseyin Baykara'nın maiyeti 22 Mart 1469 tarihinde Pavlika Dağı'nın kuzeyine eriştiğinde Herat'ın seyyidleri, asilzadeleri ve ileri gelenleri Baykara'yı hoş bir şekilde karşıladılar. Baykara'nın ordugâhı Taht-ı Hacı Bey'e vardıktan sonra 24 Mart Cuma günü Herat'taki camide Sultan Hüseyin adına hutbe okundu. Sultan Hüseyin Taht-ı Hacı Bey'den Bağ-ı Zagan'a doğru ilerledi ve Timurlu tahtına oturdu. ${ }^{5}$ Baykara, saltanatı boyunca Herat'ta Horasan ve Horasan'ın batı ve güney bölgeleri ile Harezm bölgesini elinde tutmaya çalıştı. ${ }^{6}$

\section{Yadigâr Muhammed'le Mücadele}

\section{Çınaran Savaşı}

Karakoyunlu Mirza Cihan Şah, Sultan Ebu Said ile barış yapıp Horasan'dan Azerbaycan'a dönünce Şahruh kolundan Mirza Sultan Muhammed'in oğlu Yadigâr Muhammed'in halası Payanda Sultan Begim'in tavsiyesi üzerine Mirza Cihan Şah'ın maiyetine dahil olmuştu. Yadigâr Muhammed, Cihan Şah'ın ölümünden sonra Akkoyunlu Uzun Hasan'ın himayesi altında kaldı. ${ }^{7}$ Hüseyin Baykara Herat tahtına çıkınca Uzun Hasan, Yadigâr Muhammed'i bazı Horasan emirleri ve büyük bir askeri birlikle saltanat mirasını ele geçirmesi için cesaretlendirdi. ${ }^{8}$ Yadigâr Muhammed; Şeyh Ebu'I Fazl Alike, Ebu'I Hasan-ı Tahran, Emir Şeyh Hacl, Emir Muhammed Behlül, Pir Muhammed Pirzad, Şeyh Muhammed Tagayi, Ali-yi Celayir, Pir Osman Hinduke, Sultan Ahmed Çeharşenbe ve Hüseyni Harezmî gibi çok sayıda emirle Horasan'ı almak için harekete geçti. Onlar Mazenderan'a vardıklarında Hüseyin Baykara adına buranın valiliğini yürüten Emir Şeyh Zahid Tarumi'ye karşı

\footnotetext{
${ }^{4}$ Khwandamir, Habıbu's-Sıyer, Tome Three, Çev: W. M. Thackston, Harvard 1994, ss. 420-421.

${ }^{5}$ Hasan-ı Rumlu, Ahsenü’t Tevarih, Çev: Mürsel Öztürk, Ankara 2006, s. 475.

${ }^{6}$ Babur, a.g.e., s. 64.

${ }^{7}$ Mirhand, Ravzatu's Safa, 7, Tehran, 1229 (h. ş.), s. 43.

${ }^{8}$ Mehdi Farhani Monfard, Politics and Culture at the end of the Timurid and early Safavid period (1468-1505), Tehran 2003, s. 132.
}

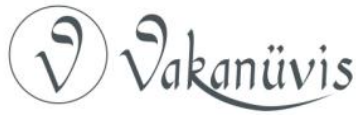


mücadele etmeye cesaret edemediler ve geri çekildiler. ${ }^{9}$ Sultan Mirza Hüseyin bu gelişmelerden haberdar olunca, Emir Nasiruddin Abdu'lHalil ve Emir Mübarizüddin Veli Bey'i bir grup askerle birlikte Yadigâr Muhammed üzerine gönderdi. Onlar Nişabur'dan Samalkan'a ilerlediler ve burada birkaç gün beklediler. Daha sonra Hüseyin Baykara Kiçik Mirza'yı onların peşinden gönderdi. Kiçik Mirza Samalkan'da onlarla birleşti ve hep birlikte Astarabad geçidinde ortaya çıkan Yadigâr Muhammed üzerine yürüdüler. Onlar Şurap'a eriştiklerinde Baykara'dan gelen mektup doğrultusunda çok yüksek ve güvenli bir yer olan Horus Yaylağı tepesinde konuşlandılar. Yadigâr Muhammed bu tepeye doğru yürüdü. Fakat Yadigâr buraya erişemeyeceğini anlayınca İsferayin'e çekildi. ${ }^{10}$

Sultan Hüseyin bu hadiseden sonra Herat'tan harekete geçti. 11 Eylül 1469 tarihinde Meşhed civarında ordugâhını kurdu. Kiçik Mirza ve emirler Sultan'ın yaklaştığı haberini alınca, Horus Yaylağı tepesinden indiler ve Baykara'nın kafilesine katıldılar. Sultan Hüseyin, adamlarından Yadigâr'ın İsferayin'e girdiğini öğrendi ve savaşmaya karar verdi. Sultan Radgan çayırına erişti, Habuşan ve Yalguz vadilerinden geçerek Habuşan'ı İsferayin'den ayıran bir sıradağa vardı. Kiçik Mirza ve emirler Sultan'ın ordugâhıyla birleştiler, Baykara'ya Yadigâr Muhammed ve Azerbaycan emirlerinin geldiğini haber verdiler. ${ }^{11}$ Sultan Hüseyin bu haberleri duyunca Seyyid Murad Oğlakçı, Mir Ali Mirahur ile bin tane süvariyi düşmanı izlemeleri için gönderdi ve savaş için hazırlık yapmaya başladı. Emir Ali Mirahur düşmanla karşılaştı ve giriştiği mücadelede galip geldi, fakat Emir Seyyid Murad Oğlakçı öldürüldü. Diğer emirler ise sağlam bir şekilde ordugâha döndüler. Baykara, bu hadise üzerine savaş hazırlıklarına başladı. Ordusunun sağ cenahına Emir Mübarizüddin Veli Bey'i, sol cenahına Kiçik Mirza'yı ve Emir Abdu'I-Halik'i komutan olarak görevlendirdi. Emir Hasan Şeyh Timur, Emir Moğol ve Emir Şeyh Ebu Said Han Darmiyan'ı birliğin ön koluna atadı. Baykara'nın kendisi de ordunun merkezine geçti. ${ }^{12}$

\footnotetext{
${ }^{9}$ Rumlu, a.g.e., s. 477.

${ }^{10}$ Khwandamir, a.g.e., s. 423.

${ }^{11}$ Mirhand, a.g.e., s. 44.

12 Mirhand, a.g.e., ss. 44-45.
}

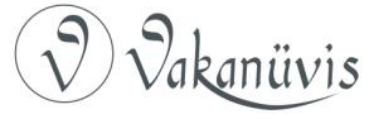


Bu sırada Yadigâr Muhammed de birliklerini düzenliyordu. Emir Ali Celayir'i sağ cenahta, Emir Ahmed Ali Farsi Barlas ve Emir Sultan Hasan Arhang'ı sol cenahta görevlendirdi. Emir Eyyub Şeyh Celayir ve Muhammed Kükeltaş'ı da birliğin ön koluna atadı. Kendisi de ordunun merkezindeydi. Her iki orduda savaş düzeni sağlandıktan sonra taraflar Çınaran'da karşı karşıya geldi. Sultan Hüseyin'in birliklerinin sağ cenahında olan Emir Mübarizüddin Veli Bey, düşmanın sol cenahına yöneldi. Emir Hasan Şeyh Timur yer değiştirerek sağ cenahtan düşmana saldırdı ve çok sayıda düşmanı öldürdü. Yadigâr Muhammed, sol cenahtaki Emir Hasan Şeyh Timur'un yokluğundan yararlanarak Sultan'ın ordusunun merkezine yöneldi. Sultan Hüseyin bu durumu fark etti ve savaşçılarına oklarını fırlatması emrini verdi. Baykara'nın askerleri karşısında mağlup olan düşman geri püskürtüldü. ${ }^{13}$ Baykara kaçan düşmanların peşine düştü, çok sayıda düşman Baykara'nın askerleri tarafından öldürüldü yada ele geçirildi. Behlül-i Kaşi, Şeyh Said Tagayi, Muhammed Kükeltaş, Emir EyyubEmir Ahmed ve Sultan Hasan Arhang ele geçirilenler arasındaydı. Emir Eyyub, Emir Ahmed ve Sultan Hasan şefaat diledikleri için bağışlandılar, fakat diğerleri öldürüldüler. Bu zaferde verdiği mücadeleden dolayı Sultan Hüseyin, Emir Hasan Şeyh Timur'u Astarabad'a vali olarak atadı. Sultan'ın kendisi de hızlıca başkent Herat'a döndü ve kışık konağı olarak Bağ-ı Sefid'i yaptırdı. ${ }^{14}$

\section{Yadigâr Muhammed'in Kısa Süren Saltanatı}

Hüseyin Baykara Herat'a döndükten sonra kışı yeni yaptırdığı Bağ-ı Sefid'de geçirmekteydi. Bu sırada Azerbaycan emirlerinin önde gelen isimlerinden Muhammed Ali Şeker'in oğlu Yar Ali Türkmen ve Bayram Türkmen, Uzun Hasan Bey'in hizmetinden ayrılan bin savaşçı ve Karakoyunlu hükümdarı Cihan Şah'ın oğlu Mirza İbrahim ile Horasan'a doğru yöneldi. Baykara'nın makamına ulaştıklarında iyi bir şekilde karşılandılar. Mültecilerin gelmesinden sonra Uzun Hasan, adamlarından Gazi Ali'yi bir mektupla Baykara'ya gönderdi. Mektupta "Senin kudretli ataların ve bizim soylu atalarımız arasında her zaman

\footnotetext{
${ }^{13}$ Khwandamir, a.g.e., s. 424.

${ }^{14}$ Rumlu, a.g.e., s. 479.
}

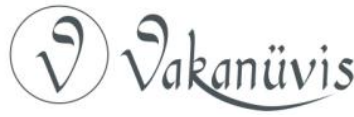


dostane ilişkiler olmuştur. Biz, Mirza Cihan Şah'ı başarılı bir şekilde geri püskürttüğümüzde Mirza Sultan Ebu Said, atalarının övgüsüne layık bir saldırıda bulundu ve askerlerini Azerbaycan'a getirdi. Biz nazikçe kendisinden rica etmemize rağmen işe yaramadı ve ondan intikam aldı. Şimdi büyüklerimizin dostluğunun devam ettirilebilmesi ve senin sarayına sığınan Karakoyunlu Türkmenlerini geri buraya gönderilmesi arzu edilmektedir" yazıyordu. ${ }^{15}$ Baykara, elçi olarak gönderilen Gazi Ali'ye kendisine sığınan mültecileri teslim etmedi. ${ }^{16}$ Mirza Yadigâr Muhammed Çınaran Savaşı'ndan sonra Damgan ve Simnan taraflarına erişince, Uzun Hasan'a Hüseyin Baykara ile yaptığı savaş hakkında bir rapor yazdı ve yardım istedi. Uzun Hasan Bey de Baykara'dan mülteciler konusunda beklediği karşılığı alamadığından Yadigâr'a yardım için akrabası Emir Yusuf Bey ve Emir Şahsuvar Karakoyunlu'nun oğlu Emir Şah Mansur ve iki bin süvariyi görevlendirdi. ${ }^{17}$ Savaş hazırlıkları için Yadigâr Muhammed Horasan'a geri döndü, burada ahaliye zulüm etti. Bu arada Yadigâr'ın bir grup ileri gelen adamı, Kayın'dan Kirman'a savaş için yöneldi ve burada Kuhistan'ın fethi için, kendilerine bin tane süvari gönderen, Uzun Hasan Bey'in oğlu Zeynel Bey'e biat etti. Yadigâr'ın adamları Emir Şeyh Zahid üzerine ani bir saldırı yaptılar ve onu öldürdüler. ${ }^{18}$ Bu haberler Herat'ta duyulunca Emir Eyyub Şeyh Celayir ve Nimet Harezmî gibi emirler Hüseyin Baykara'yı terk ederek Mirza Yadigâr Muhammed'in ordugâhına iltica ettiler. Sultan, onların kendisini terk etmesini önemsemedi. Baykara, Emir Abdu'l-Halik Bayram Türkmen ve Yar Ali Türkmen'i Yadigâr Muhammed'in maiyetine taarruz için gönderdi. Onlar Meşhed'e vardığında Yadigâr Muhammed'in Nişabur'a zarar veren bazı emirleri kaçtılar ve Yadigâr'ın İsferayin'deki ordugâhına katıldılar. Yadigâr'ın bir grup askeri Radgan çayırında Sultan'ın birliklerine saldırdı, Yadigâr Muhammed ise Sebzvar'a geldi ve burayı ele geçirdi. Sultan Hüseyin bu haberi duyduğunda kendisi harekete geçmedikçe Yadigâr meselesinin çözülmeyeceğini anladı. ${ }^{19}$ Bu yüzden büyük bir orduyla birlikte

\footnotetext{
${ }^{15}$ Khwandamir, a.g.e., s. 424.

${ }^{16}$ Rumlu, a.g.e., s. 483.

${ }^{17}$ Ebu Bekr-i Tihranî, Kitab-ı Diyarbekriyye, Çev: Mürsel Öztürk, Ankara 2001, s. 330.

${ }^{18}$ Mirhand, a.g.e., s. 49.

${ }^{19}$ Rumlu, a.g.e., ss. 482-483.
}

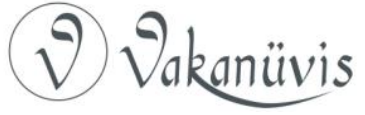


Herat'tan ayrıldı. Radgan'da kendi maiyetine saldıran gruba hücum etti ve Sebzvar'a yöneldi. Yadigâr Muhammed bunu duyunca Sebzvar'a, Kadı Bey'in yanına gitti. Kadı Bey onun en güvendiği adamlardandı. Yadigâr daha sonra Bistam ve Damgan'a yöneldi. Bir süre sonra Sultan Hüseyin ordugâhıyla birlikte Sebzvar civarına yerleşti, daha sonra bu şehri ele geçirdi. Kadı Bey ve yetmiş adamı ele geçirildi. Kadı Bey hariç diğerleri öldürüldü. Buranın ileri gelenlerinden Seyyid Nasrullah Keşani ve Hoca Muin Muhtar, Sultan Hüseyin'i desteklediklerini ifade ettiler ve ona itaat ettiler. ${ }^{20}$

Sebzvar alındıktan sonra Sultan Hüseyin'in birlikleri Yadigâr Muhammed'in peşine düştü. Pencdih'de ordugâh kurulduğunda Yadigâr Muhammed'in izcileri, Baykara'nın bölgedeki karavullarıyla karşılaştı ve Cacerm köprüsünde mücadele vuku buldu. Yadigâr Muhammed'in izcileri mağlup oldu. Emirlerden Nimet Harezmî, Abdullah Celayir, Kasım Devlet Malik ile birlikte bazı şahıslar tutsak edildi. Sadece Uzun Hasan Bey'in görevlisi olan bir şahıs öldürüldü. Baykara'nın ordusu daha sonra buradan Cacerm'e ilerledi. ${ }^{21}$ Hüseyin Baykara Cacerm'de ordugâhını konuşlandırdığında, Yadigâr Mirza'nın Emir Hasan Şeyh Timur'un Astarabad'daki birliklerine saldırdığı haberi geldi. Emir Hasan Şeyh Timur, Şasman Kalesine kaçmıştı ve kendisi için uygun bir yer aramaktaydı. Bunun akabinde bir grup askerin Sultan Hüseyin'in maiyetini terk ettiği ve düşmana katıldığı haberi geldi. Bütün bu sebeplerden dolayı kumandanların Baykara'ya olan güveni sarsıldı. Baykara, bir süreliğine savaş girişiminde bulunmamaya karar verdi. Sultan Hüseyin Cacerm'den ayrılarak Meşhed'e gitti. Orada İmam Ali İbn Musa er-Rıza'nın huzurunda dualar etti. O, Poli Hatun'a vardığında Herat'ta büyük bir kargaşanın meydana geldiğini ve halka karşı zulüm yapıldığını öğrendi. Divan işlerini ele almak ve saltanat meselelerini yürütmek için Herat'ta kalan Hoca Abdullah Ahtab, Hoca Kutbeddin Tavus Semnani aleyhinde haberler ortaya attı. Hoca Tavus yakalanarak hapsedildi ve ona üç yüz bin Kepeki dinar para cezası verildi. Onun yerine, divanda müfettişlik görevini yerine getiren, Hoca Abdullah geçti. Herat ahalisinin Sultan Hüseyin'in varlığından yoksun kaldığı bu süreçte o, Hoca Nizameddin Bahtiyar Semnani ile birlikte

\footnotetext{
${ }^{20}$ Mirhand, a.g.e., s. 50.

${ }^{21}$ Tihrânî, a.g.e., s. 330.
}

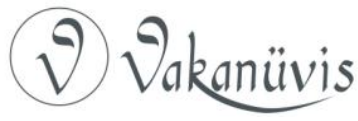


idari meselelerde söz sahibi oldu. Hoca Abdullah fakir halka ağır vergiler koydu. Bu durumdan olumsuz etkilenen bir grup ona saldırdı ve taşa tuttu. Hoca Abdullah bu hadiseden sonra bir medreseye sığındı. ${ }^{22}$

Bu haberler Poli Hatun'da bulunan Sultan Hüseyin'e vardığında, emirlerinden Ali Şir Nevai'ye hızlı bir şekilde şehre giderek Hoca Abdullah'ı yakalamasını ve ordugâhına getirmesini emretti. Emir Nizameddin, adaleti yeniden tesis etmek, zulüm ve baskıyı ortadan kaldırmak için Baykara'nın fermanıyla birlikte Herat'a gitti. Emir, burada adaletsizliğin getirdiği acıları dindirmeye ve her türlü baskıya maruz kalan insanların mağduriyetini gidermeye çalıştı. Emir, Cuma günü kürsüden Sultan'ın fermanını okudu. Ahali bu fermandan sonra sakinleşti, Sultan'a uzun bir saltanat, emire ise başarılarının devamı için dua etti. Ali Şir, ordugâha geri dönünce Hoca Nizameddin Bahtiyar tutuklandı, Hoca Kutbeddin ise yeniden divana müfettiş olarak atandı. Daha sonra Baykara, Herat'a doğru yöneldi. ${ }^{23}$ Sultan 11 Haziran 1470 tarihinde Bağ-ı Nazargah'da durdu, buradan Beşertu çayırlarına doğru gitti. Yadigâr Muhammed Baykara'nın geri döndüğünü öğrenince, Horasan'ı ele geçirme ümidi arttı ve bu yüzden Meşhed'e doğru gitti. Bu arada Sultan Mahmud Mirza Ceyhun'a doğru ilerledi ve Belh'e saldırmaya başladı. Bu haberler Sultan'ın maiyetine eriştiğinde bir grup asker kendisini terk etti. Bu vaziyet Baykara'yı endişelendirdi ve bir süre savaştan kaçınmanın iyi olacağını düşündü. Hüseyin Baykara, Beşertu'dan Sak-ı Selman'a hareket etti, fakat burası tamamen çöllerle kaplıydı ve ordugâh için elverişli değildi. Baykara bazı kaleleri ele geçirmek için Sak-ı Selman'dan Tokuz Ribat yoluyla Nerretu Kalesi'ne hareket etti. Sultan kaleye yaklaştığında kale kumandanı Ahmed Tukçi'nin gönderdiği mektupta "Eğer bir veya iki tane görevli ile gelirseniz kale kapılarını açacağım, aksi takdirde size karşı itaatimi devam ettirmeyebilirim." ${ }^{24}$ ifadelerine yer verdi.

Sultan aldığı bu haberi samimi bulmadı ve hemen Murgap'a yöneldi. Buraya geldiğinde Türkmenlerden Mirza İbrahim, Pir Ali, Yar Ali, Sultan Bayezid, Sultan Argun Devan ve Şeyh Derviş Kavçin onu terk

\footnotetext{
${ }^{22}$ Khwandamir, a.g.e., s. 425.

${ }^{23}$ Rumlu, a.g.e., s. 484.

${ }^{24}$ Khwandamir, a.g.e., s. 425-426.
}

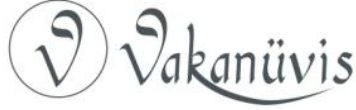


ettiler. $O$, bu duruma çok üzüldü, nereye gideceğini bilmiyordu. Çok geçmeden Emir Muzaffer Barlas'tan Yusuf adlı bir elçi haber getirdi. Elçi, Emir Pir Muhammed Arlat ve onun dört oğlunun Kayser civarında bir grup destekçi ile toplanmış olduklarını ve Sultan Hüseyin'in kararını bekledikleri haberini verdi. Sultan Hüseyin Kayser'e gitti ve Emiz Muzaffer Barlas burada ona itaatini sundu ve kendisi için ümitli olduğunu belirtti. Baykara, Kayser'den bir grup Arlatlı, Emir Pir Muhammed, onun oğulları ve akrabalarıyla birlikte yola çıktı. Sultan, yanındakilerle birlikte Meymene'ye vardığında yanında çok sayıda destekçi ve taraftar başkente yönelmek için bekliyordu. Baykara buradan Herat'a yöneldi. ${ }^{25}$ Akkoyunlu Uzun Hasan'ın oğlu Sultan Halil Mirza Astarabad'a hareket edince Yadigâr Muhammed, Şehzade Halil'in hareketinden önce Irak'tan yardıma gelmiş olan Akkoyunlu emirleri ile birlikte Horasan'a yöneldi. ${ }^{26}$ Yadigâr Muhammed Cam'a eriştiğinde Herat'ın ileri gelenlerine ve soylulara uzlaşmak için haber gönderdi ve şehrin kuzeyine geçti. Şehrin ileri gelenlerinden bazılarının Yadigâr Muhammed'i desteklediğini gören Baykara, Murgap'a doğru ilerledi. ${ }^{27}$ Buradan da Meymene ve Faryab'a doğru gitti. ${ }^{28}$ Sultan Yadigâr Muhammed, Herat yakınlarında Ribat-i Sencab istikametine yaklaştığında seyyidler, soylular, büyük rütbeliler onu karşıladılar. Yadigâr, kendisini karşılamaya gelenlere karşı hürmetlerini ve şükranlarını sundu. Sultan o gün Kuhistan civarına ordugâhını kurdu. Daha sonra Bağ-ı Zagan'a gitti ve Şahruh'un kendi soyundan gelenlere bıraktığı tahtına oturdu. ${ }^{29}$ Uzun Hasan Bey'in akrabalarından Sultan'a yardım eden Azerbaycan'ın bazı emirleri Kuhistan'ı ikamet yeri olarak seçtiler ve onların hepsi önceki Sultan'ın saray ve meskenlerine atandılar. ${ }^{30}$ Hutbenin önce Uzun Hasan Bey adına, sonra da Mirza Yadigâr Muhammed adına okunmasına karar verildi. ${ }^{31}$ Şehzade Sultan

\footnotetext{
${ }^{25}$ Mirhand, a.g.e., s. 53.

${ }^{26}$ AbûBakr-i Tihrânî, a.g.e., s. 331.

${ }^{27}$ Muinüddin Muhammed el-İsfizari, Ravzatü'l cennet fi evsafi medineti'l Herat, Tehran 1338 (h. ş.), s. 350.

28 ismail Aka, Timur ve Devleti, Ankara 1991, s. 95.

${ }^{29}$ Kemal al-Din 'Abd al-Razzaq Samarqandi, Matla'-i Sa'dayn wa Majma'-i Bahrayn, 2.,Haz: Nawâ'i, 'Abd al-Husayn, Tehran 2004, s. 1042.

30 isfizari, a.g.e., s. 350.

${ }^{31}$ Monfard, a.g.e., s. 134.
}

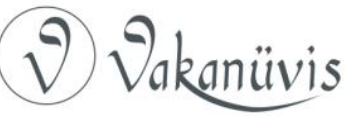


Halil, o günlerde Astarabad vilayetini alıp Meşhed'e kadar olan bölgeyi hâkimiyetine geçirdikten sonra Yadigâr Muhammed'i güçlendirmek amacıyla yavaş yavaş ilerledi. Gideceği istikamette bulunan yerleri ele geçirdi, beldelerde ve köylerde darugalar görevlendirdi. ${ }^{32}$ Yadigâr Muhammed tahta oturduğunda Hoca Kutbeddin Tavus Simnani divana müfettiş olarak atandı. İdari ve mali meselelerden Payanda Sultan Begim sorumlu oldu. Sultan zevk ve sefaya alıştığı için zamanının çoğunu içki içerek, ud ve arp dinleyerek geçiriyor, saltanat meselelerine hiçbir şekilde dikkat etmiyor ve yanlışlarını düzeltmek için herhangi bir girişimde bulunmuyordu. ${ }^{33} \mathrm{Bu}$ yüzden Türkmen emirler Horasan'ın bütün bölgelerinde rahatça çaresiz insanlara zulmediyordu. Baskılardan dolayı çok sayıda insan evini terk etti. Uzun Hasan Bey'in oğlu Sultan Halil, Radgan sahasında ordugâh kurdu, buradaki insanlara eziyet etti, Halil'in kardeşi Zeynel Bey de Kuhistan'da bulunan ahaliye baskı uyguluyordu. ${ }^{34}$

\section{Baykara'nın Yeniden Herat Tahtına Çıkması}

Yadigâr Muhammed Herat'ta tahta oturduktan sonra Uzun Hasan'ın emirlerinin eziyetine maruz kalan ahaliye yardımda bulunmuyor, olup bitene kayıtsız kalıyordu. Baykara bu durumdan haberdar olunca emirlerine şöyle dedi: "Ben dünyanın bir yerinde hayatta olayım da İslam diyarında böyle zulüm olsun. Bu reva mıdır?" O sırada Baykara'nın yanında olanlar "Binlerce can senin uğrunda feda olsun. Biz bu yapılacak savaşı cihad-ı ekber biliriz" dediler. ${ }^{35}$ Baykara Meymene'ye ordugâhını kurduğunda Yadigâr Muhammed sarhoş, uyuşuk bir vaziyetteydi. 0 , devlet işleriyle ilgilenmiyordu, Horasan'da emniyet iyice kaybolmuştu. Yöneticiler çok fazla hata yapıyor, dini kurumlar parçalanıyordu. Bu durum, Sultan Hüseyin'e zafer elde edeceği cesaretini veriyordu. Sultan Hüseyin Baykara, Herat'a ani bir saldırı yapmaya ve bütün muhaliflerini ortadan kaldırmaya karar

\footnotetext{
32 Tihrânî, a.g.e., s. 332.

33 isfizari, a.g.e., s. 364.

${ }^{34}$ Mirhand, a.g.e., s. 55.

${ }^{35}$ Devletşah, Tezkire-i Devletşah, çev: Necati Lügal, İstanbul 1977, s. 605.
}

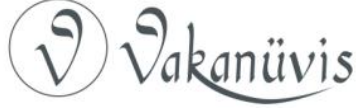


verdi. ${ }^{36}$ Sultan bu karara vardıktan sonra ordusunun merkezi ile sağ ve sol cenahlarını düzene koydu. ${ }^{37}$ Baykara daha sonra ordusunu Murgap üzerine sevk etti ve sekiz yüz elli askerle birlikte merkeze doğru hızla ilerledi. Gece yarısı Bağ-ı Ribat'ta durdu, ertesi gün kuşluk vaktinde Baba Haki adında bir dervişin meskenine doğru ilerledi. Baba Haki gençlik çağlarından yaşlanıncaya kadar insanlarla iletişim kurmaktan kaçınmış ve zamanını dağlarda dolaşarak Allah'a ibadet etmekle geçirmişti. Sultan Hüseyin'in yaklaştığını duyunca alışkanlıklarını terk etmiş ve Sultan'a kendisiyle tanışmak istediğini ifade etmişti. Baba Haki Sultan'ın dikkatini cezbetti. Sultan'a bazı hediyeler sundu ve onu kendi mekânına davet etti. Baykara bu daveti kabul etti ve güneş doğuncaya kadar onun evinde konakladı. Sultan sabah olunca tekrar yola çıktı, derviş bir müddet ona eşlik ettikten sonra mızrağını Sultan'a verip geri döndü. Hem Sultan Hüseyin hem de askerler Baba Haki'nin yanında kaldıkları sürede ondan zafer ve başarı elde edeceklerine dair ilham aldılar. $^{38}$

Manen güçlenen Sultan, Havadastak istikametinde ilerledi. Karanlık çöktüğünde Serim Karavul'u keşif için önden gönderdi. Sultan ve adamları Havadastak çöllerindeyken Yadigâr Muhammed'den gelen bir kişi Sultan'ın ordugâhına vardı. Bu şahsın verdiği bilgiye göre düşman Sultan ve maiyetinin yaklaştığından tamamen habersizdi. Sultan daha da hızlandı ve çok geçmeden Serim Karavul, Sultan'a bir mektup gönderdi. Serim Karavul'dan gelen mektupta kısaca Baykara'nın başkente doğru ilerlediğinden kimsenin haberdar olmadığı yazıyordu. ${ }^{39}$ Sultan Hüseyin 21 Ağustos 1470 tarihinde, ordusuyla birlikte Kezdavak'a vardı. Askerler burada savaş için hazırlık yaptılar. Sultan'ın kumandanlarından Emir Muzaffer Barlas, Şeyh Ebu Said Darmiyan, İbrahim Barlas ve Derviş Ali Arlat yüz elli cesur asker ile birlikte Bağ-ı Zagan kapısına doğru ilerlediler. Hacı Muhammed Hüsrev, keşif için hareket etti ve Bağ-ı Zagan'a vardıktan sonra elde ettiği bazı bilgilerle geri döndü. Hacı Muhammed Hüsrev, Yadigâr Muhammed'in sarhoş

\footnotetext{
${ }^{36}$ Talip Yıldırım, Hüseyin Baykara Divanı, İstanbul 2010, s. 15.

${ }^{37}$ Devletşah,a.g.e., s. 605.

${ }^{38}$ Mirhand, a.g.e., s. 58.

${ }^{39}$ Khwandamir, a.g.e., s. 427.
}

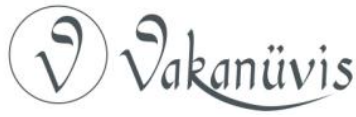


olduğunu bildirdi. Bunun üzerine Baykara, Hıyaban yolunda hızla ilerledi. ${ }^{40}$

Baykara Allame Razi'nin türbesine varınca Kiçik Mirza'yı Emir Muzaffer'e yardım için gönderdi. Dulig Özbek ve Sultan Hoca Özbek bir grup Özbek askeriyle birlikte bahçe kapısına sevk edildi. Mirza Sultan Ahmed $^{41}$, Hoca Abdu'l-Velid Ahmed'in mezarının olduğu kapıya gönderildi. Emir Nasuriddin Abdu'l-Halik ve Emir Vali Beg, Emir Firuz Şah'ın evine gönderildi. Sultan, seksen askeriyle birlikte Emir Muzaffer'in arkasından gitti. Emir Muzaffer'in yanından gelen Yadigâr Mirahur, kumandanların Bağ-ı Zagan kapısını aştıkları ve içeri girdikleri haberini verdi. Bu haberi alan Sultan, hemen Yadigâr Muhammed'in kendisinden geçtiği Bağ-ı Şimal'e yöneldi. Bekçiler ve muhafızlar engel olmaya çalıştıysa da fayda etmedi. Balta ile kapılar kırıldıktan sonra Baykara ve askerler içeriye girdi. Bu sırada bir kadınla sarhoş vaziyette uyumakta olan Yadigâr Muhammed kulağına gürültülerin gelmesiyle aniden yerinden sıçradı ve bağın bir tarafına gizlenmek istedi. Askerler onu yakalayıp Baykara'nın huzuruna getirdiler. ${ }^{42}$ Baykara huzuruna getirilen Yadigâr Muhammed'i yaptıklarından dolayı aşağıladı. Sultan daha sonra cellatlara emrederek onu öldürttü. ${ }^{43}$ Türkmenler o gece sabaha kadar gruplar halinde Herat'tan kaçtılar. Baykara'nın emirleri düşman emirlerini tutsak ettiler. Yakalanan emirler arasında daha önce kendisine ihanet ederek Yadigâr Muhammed'in tarafına geçen Emir Celayir öldürüldü, diğerleri ise affedildi. ${ }^{44}$

Bu haber Akkoyunlu Uzun Hasan'a ulaşınca İsfahan'da bulunan oğlu Uğurlu Muhammed'e haber göndererek Astarabad'da bulunan Sultan Halil'in yanına gitmesini emretti. Luristan seferinden yeni dönmüş olan

\footnotetext{
${ }^{40}$ Mirhand, a.g.e., s. 59.

${ }^{41}$ Burada adı geçen Mirza Sultan Ahmed, Sultan Ebu Said Mirza'nın Semerkand hakimi oğlu ile aynı şahıs değildir. "Mirza" Timurlu şehzadeleri için kullanılan bir unvan olsa da burada Hüseyin Baykara'nın maiyetinde bulunan askerlerden birinin ismidir.

${ }^{42}$ Khwandamir, a.g.e., s. 428.

${ }^{43}$ Samarqandi, a.g.e., s. 1043.

${ }^{44}$ Devletşah, a.g.e., s. 606; Tihrânî, a.g.e., s. 333; Samarqandi, a.g.e.,s. 1042;

H. Beveridge, "Hüseyin Mirza", İslam Ansiklopedisi, 5-1, İstanbul 1987, ss. 645646.
}

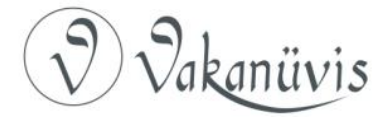


Uğurlu Muhammed aldığı ferman üzerine Astarabad'a yöneldi. Hüseyin Baykara bu durumdan haberdar olunca Şeyhülislam Şeyh Abdullah ile Uzun Hasan'a gönderdiği mektupta Astarabad'ın terk edilmesi halinde kendisinin hâkimiyetini kabul edeceğini bildirdi. Uzun Hasan bu teklifi kabul etti ve Astarabad'da bulunan şehzadeler Uzun Hasan'ın talimatıyla burayı terk ettiler. Ancak Uzun Hasan'ın Osmanlıyla olan kötü ilişkileri ${ }^{45}$ nedeniyle Astarabad'ı Baykara'ya bırakmak zorunda kaldı. ${ }^{46}$ Bütün bu hadiseler yaşanırken Baykara bir taraftan da adalet ve eşitliği garantiye alacak kanun ve fermanlar çıkardı. Bu şekilde halkın gasp edilen hakları tekrar iade edildi. Sultan'ın hâkimiyet alanının başkalarının elinde olduğu, herkesi üzen kötü günler son buldu. Seyyidler ve âlimler, Sultan'a tebriklerini sunmak için onun huzuruna geldiler ve kendisine bağlılıklarını bildirdiler. Sultan Hüseyin Baykara, Herat ve civar mahallelerdeki çiftçi, tüccar ve esnafın iki yıllı̆̆ına vergilerden muaf tutulacağını bildirdi. Sultan 23 Ağustos 1470 tarihinde Hoca Abdullah Ensari'nin türbesini ziyaret etmek için Hazargah'a gitti ve burada yaşayanlara hediyeler dağıttı. Sultan Hüseyin, Mevlana Kemaleddin Şeyh Hüseyin'i yanına çağırdı ve ona başkent Herat'ın Ebu Said döneminde olduğu gibi düzenlenmesi gerektiğini, bunun için yasal düzenlemelerin kendisi, kardeşi ve oğulları tarafından ertelenmeksizin uygulanacağını belirtti. Sultan vakit kaybetmeden bütün resmi görevliler tarafından kabul edilen emirlerini yayımladı. Dini kurum ve yasaları güçlendirmek için büyük gayret gösterdi. ${ }^{47}$

Mirza Uluğ Bey ve Sultan Ebubekir Mirza Kabil'den Belh'e gitmiş, kardeşleri Sultan Mahmud Mirza ile birlikte burayı kuşatmış, sonra Merv'e yönelmişlerdi. Sultan bu haberleri duyunca ordusuyla birlikte Merv'e doğru harekete geçti. Sultan Bend-i Çerkes'de iken düşmanları onun yaklaştığını öğrenince kaçtılar. Mirza Uluğ Bey ve yandaşları, Sultan'ın askerlerine karşı direnemeyeceklerini biliyorlardı ve kırsal bölgelere doğru kaçmayı uygun buldular. Sultan, Merv'e muzaffer bir

\footnotetext{
${ }^{45} \mathrm{Bu}$ dönemde Osmanlı-Akkoyunlu ilişkileri hakkında ayrıntılı bilgi için bkz; Remzi Kılıç, "Fatih Devri (1451-1481) Osmanlı-Akkoyunlu ilişkileri", Erciyes Üniversitesi Sosyal Bilimler Enstitüsü Dergisi, 14, Kayseri 2003, ss. 94-118.

${ }^{46}$ Seyfettin Erşahin, Akkoyunlular, Ankara 2002, s. 76.

${ }^{47}$ Mirhand, a.g.e., ss. 61-62.
}

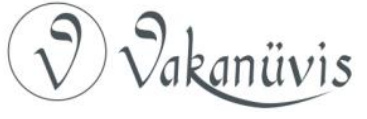


şekilde girdi ve burayı kışlık mesken yaptı. Sultan uzun bir süre buranın iyileştirilmesi için burada kaldı ve ahalinin refahını sağladı. ${ }^{48}$ Ancak Belh hala Sultan Mahmud'un hâkimiyetinde idi. ${ }^{49}$

\section{Sultan Mahmud Mirza ile Mücadeleler}

Sultan Ebu Said, üçüncü oğlu olan Sultan Mahmud Mirza'ya Astarabad'ın idaresi vermişti. Mahmud Mirza, babasının Azerbaycan'da Uzun Hasan ile giriştiği mücadelede hayatını kaybetmesi üzerine Horasan'a geldi. ${ }^{50} \mathrm{O}$, Horasan'a ilerlerken yolda Sultan Ebu Said'in askerlerinin çoğu onun emrine girdi. Sultan Mahmud, Cam civarında Emir Veli Bey ile giriştiği mücadelede mağlup oldu ve Herat'a gitti. Fakat Sultan Hüseyin'in Herat'a doğru yöneldiğini öğrenince buradan ayrıldı. ${ }^{51}$ Sultan Mahmud Mirza'nın Horasan'a yaklaştığını öğrenen bölge ahalisi de onun varlığından rahatsızlık duymuştu. O, kardeşi Sultan Ahmed Mirza ile Semerkand'a döndü. Mahmud Mirza, birkaç ay sonra Ahmed Muştak, Seyyid Bedir, Hüsrev Şah ve diğer bazı şahıslar ile birlikte Hisar'a gitti. Mahmud Mirza, o günden itibaren Kuhka ve Kühten dağlarının güneyindeki Tirmiz, Çağanyan, Hisar, Hutlan, Kunduz, Baglan ve Bedehşan', $1^{52}$ idaresi altına aldı. Babasından kendisine kalan Astarabad elinden çıkmıştı. ${ }^{53}$

Mirza Yadigâr Muhammed, Horasan'a ilerlemesi üzerine Sultan Mahmud Mirza da Belh'e gelmiş ve burayı kuşatmıştı. Sultan Hüseyin adına bölgenin idaresini elinde tutan Emir Moğol ile Sultan Ali Kiçkine, kale kapısını güçlendirdiler ve Sultan Mahmud Mirza'nın askerlerine

\footnotetext{
${ }^{48}$ Khwandamir, a.g.e., s. 429.

${ }^{49}$ Hayrunnisa Alan, Timurlular 1360-1506, İstanbul 2007, s. 218.

${ }^{50}$ Babur, a.g.e., s. 163

${ }^{51}$ Devletşah, a.g.e., s. 599.

52 Baburnâme'ye göre Sultan Ebu Said Han, vefat ettiğinde Bedehşan'ın idaresi Ebubekir Mirza'da kalmıştı. Baburnâme'nin ilerleyen bölümlerinde ise Hisar, Hutlan, Kunduz, Baglan ile birlikte Bedehşan'ın Sultan Mahmud Mirza'nın idaresine geçtiği ifade ediliyor. Fakat Handmir'in Habib-us Siyer'inde Hüseyin Baykara ile Ebubekir Mirza arasında yaşanan mücadelelerde Bedehşan'ın hala Ebubekir Mirza'nın hakimiyetinde olduğunu görüyoruz.

${ }^{53}$ Babur, a.g.e., s. 165-166
}

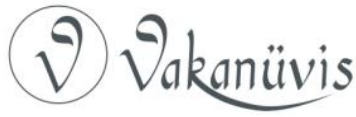


karşılık verdiler. ${ }^{54}$ Sultan Mahmud Mirza, Belh'i kuşatınca onun adamlarından Ahmed Muştak, Sultan Mahmud'u terk etti ve Sultan Hüseyin'in maiyetine dahil oldu. Sultan Hüseyin'in Belh'teki kumandanlardan Sultan Ali Kiçkine ise Sultan Mahmud'un tarafına geçmişti. Sultan Ali Kiçkine, Akaşe kapısını Sultan Mahmud'un askerlerine açtı ve onun Belh'i fethetmesini sağladı. ${ }^{55}$ Mahmud Mirza Belh'i ele geçirdikten sonra Emir Moğol'u mahkûm etti ve onu güvendiği adamlarından Yadigâr Ataka'nın kontrolünde Semerkand'a gönderdi. Yadigâr Ataka, Belh'den ayrıldıktan sonra Sultan Hüseyin'in tarafına geçmeye karar verdi. O, Emir Moğol ile birlikte Merv'e giderek Baykara'nın maiyetine dahil oldu. ${ }^{56}$ Sultan Mahmud Mirza'nın emirleri büyük bir askeri birlik ile Murgap civarına erişmiş ve orada kışı geçirmekte olan Emir Pir Muhammed Arlat, Emir Muzaffer Barlas ve Emir Kerimdad'ı mağlup etmişti. Emir Pir Muhammed ağır bir yara almış, Emir Kerimdad ise tutsak edilmişti. Bu olaydan haberdar olan Baykara, Sultan Mahmud'la mücadele için Murgap'a doğru harekete geçti. ${ }^{57}$ Sultan Hüseyin'in ordusu düşmana doğru ilerledi ve Çekmen mevkiine geldi. Daha sonra Almas'a yönelen Baykara, burada askerlerine zırhlarını giymeleri talimatı verdi ve Andhoy'a doğru ilerledi. ${ }^{58}$

Baykara Çekmen'de durduğunda Sultan Mahmud Mirza çok sayıda askeriyle Belh'den hareket etti ve Belçheragh'ı geçerek Meymene'de durdu. Mirza, burada Baykara'nın maiyetine saldırmak için plan yaptı. Ertesi gün Sultan Hüseyin'in askerleri savaş için zırhlarını kuşandılar. Sultan'ın kendisi de savaş kıyafetlerini giyindi, atına bindi ve ordusunu düzenlemeye başladı. Sultan Hüseyin'in ordusunun sağ cenahında büyük kardeşi Baykara komutayı ele aldı. Bu esnada Hasan Şeyh Timur ve bir grup cesur asker yardım için Hüseyin Baykara'nın ordugâhına geldi. Baykara'nın ordusunun sol cenahı, Mirza Sultan Ahmed'in kumandasına verilmişti. Bu sırada Şeyh Abdullah Abbasi ve Emir Abdülhalik-i Firuzşah da çok sayıda asker ile birlikte yardıma

\footnotetext{
${ }^{54}$ Rumlu, a.g.e., s. 508.

${ }^{55}$ Khwandamir, a.g.e., s. 429.

${ }^{56}$ Rumlu, a.g.e., s. 508.

${ }^{57}$ Khwandamir, a.g.e., s. 430.

${ }^{58}$ Rumlu, a.g.e., s. 508.
} 
gelmişlerdi. Hüseyin Baykara'nın ordusunun öncü kolunda Emir Muzaffer Barlas, Emir Ahmed Ali Farsi, Şeyh Ebu Said Han Darmiyan, Mir Moğol ve Altun Işık görevlendirilmişlerdi. ${ }^{59}$ Sultan Mahmud da ordusunu belirli bir düzene soktu, ordunun sağ ve sol cenahlarını güçlü askerler ve yetenekli kumandanlar görevlendirdi. ${ }^{60}$ Sultan Hüseyin'in birlikleri düşmanın savunma hattını parçaladılar ve ağır zayiat verdiler. ${ }^{61}$ Sultan Mahmud'un sağ cenahında bulunan Kanber Ali Mirahur, bir grup askeriyle gelerek Emir Hasan Şeyh Timur'a saldırdı. Emir Hasan Şeyh Timur, oldukça tedbirli hareket ederek adamlarıyla birlikte siperleri tuttu ve yerinden hareket etmedi. Sultan Hüseyin, onun düşmanla birlikte hareket ettiğini sandı. Bu yüzden Emir Muhammed Ali Ataka ve Emir Kitabdar Derviş Ali'yi beş yüz süvari ile birlikte Emir Hasan Şeyh Timur'un tarafına gönderdi. Düşman askerleri saldırıya geçince Emir Hasan Şeyh Timur, yanındaki askerleriyle birlikte siperleri aşarak onları dağıttı. Bu esnada Sultan Ahmed Mirza; Emir Şeyh Abdullah, Emir Muzaffer Barlas ve yanlarındaki bir grup asker düşmanın ordusunun sol cenahını mağlup ettiler. ${ }^{62}$

Bu esnada Baykara'nın sol cenahından Mirza Sultan Ahmed, Emir Şeyh Abdullah, Emir Abdülhalik, Budak Sultan, Devlet Hoca Özbek; öncü birliklerden Emir Muzaffer Barlas, çok sayıda askerle saldırıya geçtiler. Sultan Mahmud Mirza'nın askerleri Sultan Hüseyin'in birliklerine karşı çok fazla direnemediler. ${ }^{63}$ Burada vuku bulan savaş neticesinde Sultan Hüseyin'in adamları düşmana karşı galip geldiler. Sultan Mahmud Mirza, kaçış yolunu tutmuşu. Bu sırada Sultan Mahmud'un yaklaşık iki yüz adamı Sultan Hüseyin'in maiyetiyle karşılaştı. Sultan, onları püskürtmek için giriştiği mücadelede atı tökezleyince yere düştü. Düşman onu yakalayarak yola koyuldu. Sultan Mahmud'un askerleri, bir müddet ilerledikten sonra Sultan Mahmud'un yenildiği haberini alınca Sultan Hüseyin'i bırakıp kaçtılar. Sultan Hüseyin, düşmanın bu şekilde mağlup edilmesinden sonra

\footnotetext{
${ }^{59}$ Khwandamir, a.g.e., s. 430.

${ }^{60}$ Rumlu, a.g.e., s. 509.

${ }^{61}$ Khwandamir, a.g.e., s. 430.

${ }^{62}$ Rumlu, a.g.e., s. 509.

${ }^{63}$ Khwandamir, a.g.e., s. 431.
} 
Herat'a doğru ilerledi. ${ }^{64}$ Baykara savaştan sonra büyük yararlılık gösteren kumandanlarını ödüllendirdi. Bunların arasında cesurca mücadele etmiş, zaman zaman yaralanmış olan Ahmed Muştak'ı Belh'e vali tayin etti. ${ }^{65}$ Sultan Hüseyin, Mirza Sultan Mahmud'un Belh'i ele geçirme girişimini her ne kadar engellemiş olsa da daha sonra buraya atadığı Ahmed Muştak, bağımsız hareket etmeye başladı ve isyan etti. Ahmed Muştak, bu isyanda en büyük desteği Sultan Mahmud Mirza ve onun kardeşi Sultan Ahmed'den görmüştü. ${ }^{66}$ Daha sonra Sultan Mahmud Mirza, Emir Derviş Ali'nin Belh'de Sultan Hüseyin'e karşı isyanında da onu desteklemekten geri durmadı. ${ }^{67}$ Dolayısıyla Sultan Hüseyin, kendisine karşı çıkan her isyanda Sultan Mahmud Mirza'nın isyancılara destek vermesinin kendisi için bir tehlike oluşturduğunun farkındaydı.

Sultan Hüseyin Mirza, Emir Derviş meselesini hallettikten sonra Emir Ali Şir'i Belh'e bırakıp, kalabalık bir orduyla Bedehşan tarafına doğru yöneldi. Sultan Mahmud Mirza, bu büyük ordunun geldiğini öğrenince Hisar-ı Şadıman'dan çıkıp Çağaniyan dağına konuşlandı ve Emir Hüsrev Şah'ı çağırdı. Hüsrev, kardeşleri Emir Veli ve Pir Veli'yi bölgede bıraktı. Sultan Hüseyin, Erheng kasabasına inince Emir Cihangir Barlas ve Sultan Üveys Mirza, Vahş vilayetine saldırdılar, burayı istila ettikten sonra karargaha geri döndüler. ${ }^{68} \mathrm{Bu}$ sırada Emir Zünnün Argun, Sultan Hüseyin'e biat etmek üzere Zemindaver'den gelmişti. Fakat Emir Zünnün askerleriyle birlikte Belh'e vardığında Sultan Hüseyin şehirden ayrılmıştı. Bunu öğrenen Zünnün, altmış savaşçısıyla birlikte Baykara'nın askerlerine katılmak üzere hızla Erheng'e doğru hareket etti. ${ }^{69}$ Emir Zünnün'ün az sayıda askeriyle Kunduz'a yetiştiği haberi duyulunca yedi yüz kişiden oluşan bir ordu onları ablukaya aldı. Askerler itiraz etmesine rağmen Zünnün, Emir Veli'nin askerleriyle burada mücadeleye girişti. Emir Zünnün ilk

\footnotetext{
${ }^{64}$ Rumlu, a.g.e., ss. 509-510.

${ }^{65}$ Khwandamir, a.g.e., s. 431.

${ }^{66}$ Mirhand, a.g.e., s. 77.

${ }^{67}$ Wilhelm Barthold, "Mîr Ali Şir Nevaî ve Siyasi Hayatı", çev: Abdullah Caferoğlu, Ülkü Halkevleri Dergisi, 10/61, Ankara 1938, s. 363.

${ }^{68}$ Rumlu, a.g.e., s. 603.

${ }^{69}$ Rumlu, a.g.e., ss. 603-604.
}

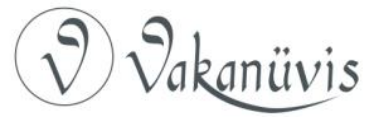


hücumda düşmana zayiat vermiş, ancak ağır bir yara almıştı. Düşman kuvvetleri oldukça kalabalık olduğu için Emir Zünnün'ün adamları onu terk ettiler. Yalnız kalan Zünnün, düşman Kunduz askerleri tarafından yakaladı. ${ }^{70}$ Emir Veli, onu Kunduz'a gönderdi ve tedavi ettirmek için hekim çağırttı. ${ }^{71}$

Bu haberler Sultan Hüseyin'e erişince Kunduz tarafına hareket etti. $\mathrm{O}$, savaşçılarıyla birlikte Zengi çayının kıyısına inerek Kunduz'u kuşattı. Sultan Mahmud Mirza, Kunduz'un kuşatıldığını duyunca Muhammed Elçi Boğa'yı bin süvari ile birlikte Baykara'nın üzerine gönderdi. Elçi Boğa, kimsenin bilmediği bir geçitten Ceyhun'u geçti ve gece yarısı Sultan Hüseyin'in ordugâhının yakınlarına varıp nakkare çalarak gürültü çıkardı. Sultan Hüseyin, bu sesleri duyunca tellalların hiçbirinin çadırdan ayrılmaması, düşmanın çıkardığı seslere kulak asılmaması hususundaki ikazını emirlere ve askerlere ulaştırmalarını buyurdu. Baykara, oğlu Ebu'l-Muhsin Mirza'yı üç bin kadar süvariyle düşmanı bu civardan uzaklaştırmak için gönderdi. ${ }^{72}$ Ebu'l-Muhsin Mirza, Ceyhun nehri yakınlarında düşmanla karşılaştı ve hemen savaş cereyan etti. Muhammed Elçi Boğa, Ebu'l-Muhsin karşısında dayanamadı ve bir sandala binerek kaçmaya çalıştı, ancak okla vurularak öldürüldü. Ayrıca onun seksen adamı bu mücadelede öldürüldü. Ebu'l-Muhsin Mirza elde ettiği bu başarıdan sonra karargâhına döndü. Yaşanan hadiseleri Sultan Mahmud Mirza duyunca büyük bir korkuya kapıldı ve barış istedi. Emir-i Bozorg-i Tirmizi'yi anlaşma ve barış görüşmeleri için Sultan Hüseyin'in huzuruna gönderdi. ${ }^{73}$ Tirmizi'nin gelişiyle iki taraf arasında barış sağlandı. Ayrıca tutsak edilmiş olan Emir Zünnün'ün gönlü alınmış, kendisine değerli hediyeler takdim edilmişti. Emir Zünnün, daha sonra Muhammed Bekir'in refakatinde Sultan Hüseyin'in yanına gönderildi. ${ }^{74}$ Sultan Hüseyin, bu barıştan sonra Belh'e doğru hareket etti. Baykara, Belh'e vardıktan sonra Haydar Muhammed

\footnotetext{
70 İsmail Aka, "Zünnûn Beg Argûn", İslâm Ansiklopedisi, 13, İstanbul 1986, s. 657.

${ }^{71}$ Khwandamir, a.g.e., s. 449.

${ }^{72}$ Rumlu, a.g.e., s. 604.

${ }^{73}$ Rumlu, a.g.e., s. 604.

${ }^{74}$ Hayrunnisa Alan, "Zünnün Argun”, İslam Ansiklopedisi, 44, Türkiye Diyanet Vakfı Yayınları, İstanbul 2011, s. 574.
}

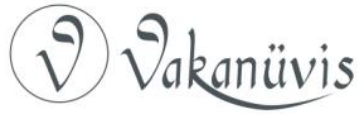


Mirza'yı buraya vali tayin etti, Emir Mübarizüddin Veli Bey'i de buranın idari meseleleri ile ilgilenmekle görevlendirdi. Daha sonra Baykara ve askerleri Herat'a geri dönmek üzere yola çıktı. Onlar, Murgap'ı geçerek Pencdih yoluyla Bağ-ı Cihanara'ya vardı. ${ }^{75}$

\section{Muhammed Ömer Mirza ile Mücadeleler}

Yadigâr Muhammed'in Horasan'ı bir süre işgal etmesi neticesinde bazı şahıslar Sultan Hüseyin'in maiyetini terk etmişti. Emir Timur'un soyundan Sultan Halil Mirza'nın oğlu Muhammed Ömer Mirza, Yusuf Tarkan ve bir grup kumandan ile 19 Haziran 1470 tarihinde Sak-I Selman'ı terk ederek Germsir ve Kandahar'a doğru kaçmıştı. O ve yanındakiler Sultan Said'in kumandanlarından birinin oğlu olan Emir Nizameddin Ahmed'in yanına ulaştığında Kandahar'ın valisi Tükal Barlas Muhammed, Ömer Mirza'ya bağııı̆̆ını bir mektupla bildirdi. Muhammed Ömer Mirza, aldığı bu mektuptan sonra Kandahar'a girdi ve buranın idaresini ele geçirdi. ${ }^{76}$ Sultan Hüseyin, Sultan Mahmud Mirza meselesiyle ilgilenirken Muhammed Ömer Mirza, bu durumu fırsat bilerek büyük bir askeri birlikle Kandahar'dan Kuhistan'a ilerlemiş ve burayı tahrip etmişti. Muhammed Ömer Mirza'nın ahaliye zulüm ettiği haberini alan Baykara Kuhistan'a, buradan da İsfendar'a ilerledi. Baykara, burada düşman izcilerinin yaklaştığı haberini alınca askerlerini onların üzerine gönderdi. Askerler dokuz kişiyi yakaladılar ve Sultan'ın huzuruna getirdiler. Sultan onlara Muhammed Ömer Mirza hakkında bazı sorular sordu ve bu şekilde onun hakkında bilgiler edindi. Sultan Hüseyin, dört bin süvarisini Muhammed Ömer Mirza üzerine gönderdi. Muhammed Ömer Mirza, Sultan Hüseyin'in askerlerinin üzerine doğru geldiğini öğrenince hemen maiyetiyle birlikte kaçtı. Sultan'ın bir grup askeri onları takip etti. Düşmanın peşine düşen Sultan'ın askerleri, Ömer Mirza'yı yakalayamayacaklarını anlayınca geri döndüler. ${ }^{77}$ Sultan, daha sonra Herat'a geldi ve kışı burada geçirdi. Muhammed Ömer Mirza, Kandahar'a geri dönünce birliklerini topladı ve Ferah şehrine doğru yöneldi. Sultan Hüseyin, bu durumdan haberdar olunca Emir

\footnotetext{
${ }^{75}$ Khwandamir , a.g.e., s. 449.

${ }^{76}$ Mirhand, a.g.e., s. 71.

${ }^{77}$ Khwandamir, a.g.e., s. 432.
}

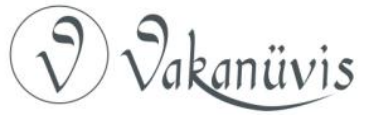


Muzaffer Barlas ve diğer kumandanlarını büyük bir orduyla birlikte düşman üzerine gönderdi. İki taraf arasında geçen savaşta Ömer Mirza okla vuruldu ve Kandahar'ın idaresi Baykara'nın eline geçti. ${ }^{78}$

\section{Ebubekir Mirza ile Mücadeleler}

Sultan Ebu Said'in oğullarından Mirza Ebubekir, babası döneminde Bedehşan'ın idaresini elinde tutmuştu. Karabağ bozgunundan sonra Emir Celaleddin Mezid Argun Bedehşan'a gitmiş, çok sayıda emir ve asker ile birlikte Ebubekir Mirza'ya itaatini bildirmişti. Bu sırada Sultan Hüseyin Mirza, Çekmen'de Sultan Mahmud Mirza'yı yenince buranın kontrolünü kendi hâkimiyetine geçirdi. ${ }^{79}$ Ebu Bekir Mirza, Sultan Hüseyin'e itaat etmek ve dostluk bağlarını güçlendirmek için Sultan'ın maiyetinden biriyle evlilik yapmaya karar vermişti. Ebubekir, düşüncelerini bildirmek amacıyla Sultan'a bir elçi gönderdi. ${ }^{80}$ Sultan Hüseyin bu önerileri duyunca çok sevindi. Baykara konu hakkında gerekli müzakereleri yaptıktan sonra Ebubekir Mirza'ya şükranlarını sunmak ve onu Herat'a davet etmek amacıyla Ali Şir'i onun sarayına göndermeye karar verdi. ${ }^{81}$ Ali Şir, Ebubekir Mirza'nın sarayına gitti ve Sultan Hüseyin'in onun bu talebine sıcak baktığını bildirdi. Daha sonra Ebubekir Mirza, Emir Celaleddin Mezid Argun ile birlikte Sultan'la görüşmek için Ceyhun'u geçti ve Sultan Hüseyin'in huzuruna geldi. ${ }^{82}$ Sultan onu sıcak ve misafirperver bir edayla karşıladı, birkaç gün şenlik ve ziyafetler organize etti. Sultan Hüseyin, ayrıca Ebubekir Mirza'yı Sultan Begüm ile evlendirdi. Baykara, Ebubekir Mirza'ya at ve cübbe, Emir Celaleddin Mezid Argun ve diğer emirlere güzel giysiler, altın, kıymetli eşyalar hediye etti. Onlar, Herat'ta bu şekilde ağırlandıktan sonra Baykara'nın da rızasıyla geri döndüler. ${ }^{83}$

Ebubekir Mirza, Bedehşan'a vardığında Emir Mezid Argun'un yanı sıra diğer emirlerle arası açıldı. Sultan Mahmud Mirza'nın da Bedehşan

\footnotetext{
${ }^{78}$ Mirhand, a.g.e., s. 72-73.

${ }^{79}$ Mirhand, a.g.e., s. 70.

${ }^{80}$ Khwandamir, a.g.e., s. 431.

${ }^{81}$ Mirhand, a.g.e., s. 70.

${ }^{82}$ Alan, Ebu Said, s. 219.

${ }^{83}$ Mirhand, a.g.e., s. 70-71.
} 
şehri üzerinde emelleri olması nedeniyle buradan ayrıldı ve tekrar Sultan Hüseyin'in huzuruna gitti. Bir süre sorunsuz bir şekilde Sultan Hüseyin'in hamiliğinde hayatını devam ettirdi. Fakat Mirza Ebubekir, Ahmed Muştak isyanı esnasında Bedehşan'a doğru kaçtı. ${ }^{84}$ Ebubekir Mirza önce Hisar-ı Şadıman'a gitti ve oradaki yerleşim alanlarını tahrip etti. Ebubekir Mirza, Bedehşan dağlarına sığındı ve Horasan'a yönünü çevirmeden önce burada ordusunu topladı. ${ }^{85}$ Ebubekir Mirza, kalabalık bir orduyla Bedehşan'dan Horasan'a geldi. Sultan Hüseyin, bu gelişmeden haberdar olunca Emir Abdu'l-Halik b. Emir, Ahmed Firuzşah'ı seçme askerlerden oluşan bin kişilik orduyla Ebubekir Mirza üzerine gönderdi. ${ }^{86}$ Ebubekir Mirza yenilerek, Belh taraflarına doğru kaçtı, daha sonra da Sistan'a gitti. Mirza, daha sonra buradan Ali Şeker'in oğlu Pir Ali ile beraber Kirman'a doğru gitti. ${ }^{87}$ Kirman valisi Ali Han Mirza, burayı terk etmek zorunda kaldı. Ebubekir Mirza Kirman'a girdi, burada birkaç ay kaldı. Bu süreçte vaktini eğlenerek ve içki içerek geçirdi. Bu haber Akkoyunlu Sultanı Yakup Padişah'a erişince Emir Bayındır'ı büyük bir askeri birlikle Kirman'a gönderdi. Ebubekir Mirza, üzerine gelen büyük orduya karşı direnemeyeceğini biliyordu, bu yüzden bir kez daha Sistan'a kaçtı. Ebubekir, Sistan'a yaklaştığında Baykara'nın, son zamanlarda ortaya çıkan, gut hastalığı nedeniyle devlet işleri ile ilgilenemeyeceğini düşünüp bu durumu fırsat bildi. Ebubekir Mirza; Bayram Bey, Pir Ali Türkmen ile diğer emirlerini ve askerlerini hemen Herat üzerine sevk etti. ${ }^{88}$

Bu sırada Baykara'nın adamlarından Can Ali Ahmed Çavlı adında bir şahıs, Mirza Ebubekir'in askerlerine rastladı. Bu askerler onu yakalayarak Mirza'nın yanına götürdüler. Mirza Ebubekir, ona Sultan Hüseyin hakkında sorular sordu. ${ }^{89}$ Can Ahmed, ona "Sultan sizin planınızı öğrendi, on veya on beş bin askeri Herat civarında pusu kurmaları için görevlendirdi. Siz oraya vardığınızda pusuya düşürülecek ve saldırıya maruz kalacaksınız. Sultan Ebu Said Mirza'nın benim

\footnotetext{
${ }^{84}$ Khwandamir, a.g.e., s. 431.

${ }^{85}$ Yıldırım, a.g.e., s. 16

${ }^{86}$ Aka, a.g.e., s. 97.

${ }^{87}$ Rumlu, a.g.e., s. 559.

${ }^{88}$ Khwandamir, a.g.e., s. 437.

${ }^{89}$ Rumlu, a.g.e., s. 560.
} 
üzerimde çok hakkı olduğu için, durumu anlatmak üzere şehirden kaçıp sizin yanınıza geldim" cevabını verdi. Ebubekir Mirza bu habere inandı ve Can Ali'yi ödüllendirdi. Mirza Ebubekir, Herat'a saldırı fikrinden vazgeçti, sonra yönünü Bakharz'a çevirdi. Can Ali de Buhara civarındaki Baykara'nın yanına gitti ve başından geçenleri ona anlattı. Sultan, ondan aldığı bu haberden sonra Ebubekir'in peşine düştü. Ebubekir, Baykara'nın yaklaştığını öğrendi ve büyük bir korku içinde Astarabad'a yöneldi. Bu süreçte Ebubekir'in adamları peyderpey onu terk ediyor, Sultan Baykara'nın birliklerine dâhil oluyordu. Baykara bu süreçte hızını iyice arttırdı, neredeyse Ebubekir Mirza'yla arasında mesafe kalmamıştı. ${ }^{90}$ Sultan Hüseyin'in askerleri Cürcan nehri kıyısında ona yetişti. ${ }^{91}$ Mirza Ebubekir, korkuya kapılarak Dihistan'a gitti ve oranın eşrafından birinin evine konuk oldu ve ondan bir at istedi. Ev sahibi Mirza'nın bu isteği üzerine ona bir at ve bir grup da asker temin ettikten sonra Sultan Hüseyin'in huzuruna giderek olup bitenden onu haberdar etti. ${ }^{92}$ Sultan Hüseyin, Kanber Ali Celayir'e bir grup askerle harekete geçerek Mirza Ebubekir'i yakalamasını emretti. Onlar da hızla Dihistan'a ilerledi ve Ebubekir'in kaldığı evinin etrafını sardı. Kanber Ali ve yanındaki askerler 17 Ocak 1479 tarihinde Mirza Ebubekir'i yakalayıp öldürdüler. Ayrıca burada Ebubekir'in hâkimiyetine giren bazı insanları da infaz ederek geri döndüler. Ebubekir'in kesilen başı Herat'a getirildi. Emir Ali Şir Nevai bu habere çok sevindi ve askerleri ödüllendirdi. Sultan Hüseyin de bu haberle rahatladı, güvenli bir şekilde Bağ-ı Cihanara'ya döndü. ${ }^{93}$

\section{Sultan Mesud Mirza ile Mücadeleler}

Sultan Ebu Said'in en büyük oğlu Semerkand'ın hakimi Sultan Ahmed Mirza, 3 Ağustos 1494 tarihinde vefat etti. Sultan Mahmud Mirza, bu haberi alınca Hisar'da bulunan oğlu Sultan Mesud Mirza'yı kendi yerine vekil tayin etti ve Semerkand'a giderek burada tahta çıktı. Diğer oğlu Baysungur Mirza'yı Buhara'ya vali olarak atadı. Ancak Sultan

\footnotetext{
${ }^{90}$ Khwandamir, a.g.e., s. 437.

${ }^{91}$ Aka, a.g.e., s. 97.

${ }^{92}$ Rumlu, a.g.e., s. 560.

${ }^{93}$ Khwandamir, a.g.e., s. 438.
}

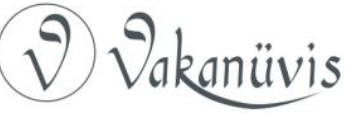


Mahmud Mirza'nın Semerkand tahtına çıkmasından bir süre sonra ölmesi üzerine Semerkand'daki beyler, Buhara valisi Baysungur Mirza'yı Semerkand'a getirerek burada tahta çıkardılar. ${ }^{94}$ Böylece Seyhun ile Ceyhun arasındaki yerler, Semerkand padişahı Baysungur ile Hisar'da kendisini padişah ilan eden Mesud Mirza arasında paylaşılmış oldu. Ceyhun ile Seyhun arasındaki toprakların iki kardeş arasında paylaştırılması Sultan Mahmud Han'ın dikkatini çekti. Doğudan Moğol Han'ı Sultan Mahmud Han, Semerkand'a saldırdı, ancak Baysungur Mirza onun ordusunu geri püskürttü. ${ }^{95}$ Sultan Mesud Mirza, Hisar'ı vekâleten yönetirken babasının ölümünü haber alınca kendi adına hutbe okutup sikke bastırdıktan sonra bağımsızlığını ilan etmişti. Diğer yandan Emir Hüsrev Şah, Sultan Mahmud Mirza döneminde Kunduz ve Baglan'ın valilik görevini yürütmüştü. $O$, Sultan Mahmud'un ölümünde sonra bağımsızlığını ilan etti. Hüsrev Şah, bir müddet Sultan Mesud Mirza'ya sadakatini bildirmesine rağmen daha sonra adamlarıla birlikte isyan etti. Bütün bu hadiseler Herat'ta duyulduğunda Sultan Hüseyin, burayı hâkimiyetine almaya karar verdi ve birliklerini topladıktan sonra 21 Eylül 1495 tarihinde Belh'e doğru yola çıktı. Baykara, ayrıca Bediüzzaman Mirza'ya Cürcan askerleriyle birlikte yola çıkması ve kendi birliklerine dâhil olması için haber gönderdi. Sultan Hüseyin, kumandanlarının tavsiyesine başvurdu. Yapılan plan doğrultusunda bazı ileri gelen adamlarıyla ordusunu Hüsrev Şah üzerine Kunduz'a gönderecek, daha sonra ordu Hisar şehrini ele geçirecekti. ${ }^{96}$

Sultan Hüseyin Mirza, kışın ordusuyla birlikte Tirmiz nehri yakınlarına gelince Sultan Mesud Mirza da ordusuyla Tirmiz karşısına geldi. Hüsrev Şah, Kunduz'da tahkimat yapmak üzere küçük kardeşi Veli'yi görevlendirdi. Kışın mühim bir kısmını nehir kenarında geçiren Baykara, suyun karşı tarafına geçemeyince tecrübesine dayanarak suyun yukarı kısmına gitti. Abdullatif Bahşi komutasında beş veya altı yüz kadar seçme adamını Kilif geçidine sevk etti. Sultan Mesud Mirza bu durumdan haberdar olunca Hüsrev Şah ile Veli hemen düşman

\footnotetext{
${ }^{94}$ Mehmet Alpargu, "Şibani Muhammed Han ve Özbek Hanlığının Yükselişi”, Gazi Üniversitesi Gazi Eğitim Fakültesi Dergisi, 8/4, Ankara 1992, s. 120.

${ }^{95}$ Babur, a.g.e., s. 167-168.

${ }^{96}$ Khwandamir, a.g.e., s. 453-454.
}

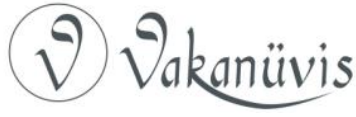


üzerine yürüme hususunda ısrar ettiler. Fakat Sultan Mesud Mirza'nın cesaretsizliği ve Veli'nin muhalifi olan Baki Çağanyani'nin sözlerine uymasından dolayı suyu geçen düşmana saldırmak yerine bozguna uğramış gibi Hisar'a döndüler. ${ }^{97}$ Hüsrev Şah'ın Hüseyin Baykara'ya karşı Sultan Mesud'u savaşa teşvik etmesi onun yeniden Sultan Mesud'un yanında olduğunu göstermekteydi.

Sultan Hüseyin, Bediüzzaman'ın yanına geldiğinde planını uygulamak amacıyla onu ordu komutanlığına tayin ederek Muhammed Veli Bey ve Emir Zünnün Argun ile birlikte Hüsrev Şah üzerine gönderdi. Muzaffer Mirza ile Muhammed Burunduk Barlas'ı da Hutlan üzerine gönderdi, kendisi ise Hisar'a doğru gitti. Sultan Hüseyin, Hisar'a yaklaştığında ahali ile birlikte Sultan Mesud onun geldiğinden haberdar oldu. Sultan Mesud, bunun üzerine Hisar'dan kaçarak, Semerkand'daki küçük kardeşi Baysungur'un yanına gitti, adamlarının bir kısmı Fergana'ya giderek Zahirüddin Muhammed Babür'ün hizmetine girdiler. Sultan Hüseyin, oğlu Ebu'l-Muhsin Mirza ile bazı adamlarını Sultan Mesud'un peşinden gönderdi. Ancak onlar başarı elde edemediler. ${ }^{98}$ Hüseyin Baykara'nın birlikleri Hisar kalesinin etrafını kuşattı. Her iki taraftan da sürekli ok ve mancınıklar atılıyordu. Birkaç gün bu şekilde devam etti, çok sayıda insan hayatını kaybetti. Savunma hattında asker sayısı oldukça azalmıştı. Hisar ahalisi Sultan Hüseyin'in komutanlarından Hasan Attar'a elçi gönderdiler. Ahali Hasan'dan Baykara'nın huzuruna gitmesini ve kendileri adına aracılık etmesini dilediler. Hoca Hasan Ali onlara acıdı ve Baykara'nın ordugâhına gitti. Hasan, Baykara'nın huzuruna geldi ve kuşatmaya alınanlar için onun affına başvurdu. Sultan Hüseyin, Hoca Hasan'ın isteğini kabul etti ve Hasan Ali ahaliye Sultan Hüseyin'in olumlu haberini bildirdi. Bu haberi alan halk ve kaledekiler çok sevindi. Sultan'a bulabildikleri en değerli malları Emir Muhammed Barlas aracilığıyla hediye ettiler. Emir Muhammed hızı bir şekilde ordugaha gitti. Sultan'a kaledekilerin hediyelerini sundu, Sultan da ona güzel cübbe ve kisveler hediye etti. Bütün Hisarlılar özür dileyerek onun merhametine sığındılar. Dolayısıyla Sultan Hüseyin, Hisar'ı kuşatsa da burayı alamadı, ahaliden

\footnotetext{
97 Babur, a.g.e., s. 171.

${ }^{98}$ Babur, a.g.e., s. 171.
}

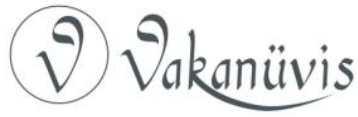


kendisinin padişahlığını tanıyacakları yolunda söz alarak, geri çekildi. ${ }^{99}$ Kunduz'da Mesud Mirza adına valilik yapan Hüsrev Şah, önce Bediüzzaman Mirza'ya daha sonra Sultan Hüseyin'e karşı başarılı bir şekilde mücadele etti, daha sonra Sultan Hüseyin ile anlaşma yaparak geri çekildi. Yapılan anlaşma gereği Hüsrev Şah hutbeyi Sultan Hüseyin adına okutacaktı. Hüseyin Baykara, bu mücadeleden maddi ve manevi zarar gördü, Hüsrev Şah'ın ünü çok arttı. Sözde Hüseyin Baykara'yı tanımakla kendi bölgesinin başında bulunmaya devam etti. Hüsrev Şah, Hüseyin Baykara çekilince Hisar’a geri dönen Mesud Mirza'yı istediği zaman hiçe saymak için kolaylık elde etmiş oldu, bundan sonra bağımsızlığa ve ülkenin daha çok dağılmasına yönelik bir adım atmış olacaktı. ${ }^{100}$

Sultan Mahmud'un diğer oğlu Baysungur Mirza babasının ölümünden sonra Semerkand'ta tahta çıksa da çok geçmeden kardeşi Sultan Ali Mirza'ya karşı başarısız olmuş, daha sonra da Semerkand'ı kuşatan Babür'e karşı direnecek gücü olmadığından Özbek sultanı Şibani Han'dan yardım istemiş ve umduğu yardımı alamamıştı. O, daha sonra çareyi Kunduz'a Hüsrev Şah'ın yanına gitmekte buldu. Emir Hüsrev Şah Baysungur ile birlikte Ceyhun'u geçtikten sonra Cağanyan'a gelerek burayı ele geçirdiler. Hüsrev Şah daha sonra Sultan Mesud'a bir elçi göndererek birlikte Semerkand üzerine gitmeyi, buranın alınmasından sonra da kardeşi Baysungur'un Semerkand'da onun ise Hisar'da kalmasını teklif etti. ${ }^{101}$ Sultan Mesud Mirza, bu haberi aldı ve düşmanların hilesini fark etmedi. Ancak Mesud Mirza endişe ettiğinden cevap da veremiyordu. Bu sırada Sultan Mahmud'un emirlerinden Emir Şeyh Abdullah Barlas, Baysungur Mirza'nın yanından ayrılıp, Sultan Mesud'un yanına gitti. Abdullah Barlas, Baysungur'un kayın pederi olduğu için Mesud Mirza'nın emirleri ona saygı gösterdiler. Sultan Mesud, Hutlan vilayetini ona verdi. Hutlan'da Sultan Mesud'un emirlerinin birçoğunun arazisi vardı, Şeyh Abdullah bu arazileri eline geçirdi. Dolayısıyla bu emirler rencide oldukları için Sultan Mesud'u terk ederek Baysungur'a iltica ettiler. ${ }^{102}$ Zafer elde edeceğine emin

\footnotetext{
${ }^{99}$ Khwandamir, a.g.e., s. 455.

${ }^{100}$ Babur, a.g.e., s. 173

${ }^{101}$ Babur, a.g.e., ss. 175-176.

102 Babur, a.g.e., s. 199.
}

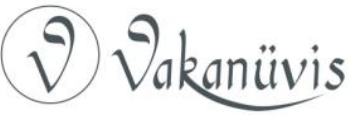


olan Baysungur, Emir Hüsrev Şah ile birlikte Çağanyan'dan ayrıldı ve Hisar’a doğru ilerledi. Karanlık çökünce Hisar kalesini kuşattılar. Sultan Mesud Mirza kuşatma öncesinde babasının inşa ettirdiği Devletsaray adlı saraya gitmişti. ${ }^{103} \mathrm{O}$, daha sonra Şeyh Abdullah Barlas ile birlikte Hutlan taraflarına doğru gitti ancak yarı yolda Şeyh Abdullah'tan ayrılarak Sultan Hüseyin'in yanına gitti. Bu sırada Bediüzzaman meselesini halletmekle uğraşan Sultan Hüseyin onu sıcak bir şekilde karşıladı, daha sonra da onu kendi kız kardeşi Begüm Sultanla evlendirdi. ${ }^{104}$

Hüsrev Şah, Baysungur Mirza'yı Hisar'da tahta çıkardı ve Hutlan'ı kardeşi Emir Veli'ye verdi. Hüsrev Şah daha sonra kış boyunca Sultan Hüseyin'in Merv bölgesinde Ebu'l-Muhsin Mirza meselesiyle uğraştığı sırada Belh'e saldırmak için fırsat elde etti. Belh'i elinde bulunduran ibrahim Hüseyin Mirza'nın askeri birlikleri zayıftı. Bu Hüsrev Şah'ı cesaretlendirdi ve Kunduz birliklerine bütün Andhoy ve Saburgan'ı yağma etmeleri emrini verdi. Hüsrev Şah'ın kendisi de Belh civarına ordugâhını konuşlandırdı ve şehri ablukaya aldı. Şehrin içindeki ve dışındaki askerler birkaç gün savaştılar. İbrahim Hüseyin Mirza zaman zaman kaleden çıkıyor ve bazı Kunduzluları öldürüyordu. Bir gün Hüsrev Şah'ın adamlarından, Kunduz ve Baglan'ın ileri gelenlerinden Nazar Bahadır, suyollarını kesmek için hendeğe doğru yöneldi. ${ }^{105}$ İbrahim Hüseyin Mirza'nın adamlarından Emir Tanrıverdi, Samançı yetmiş seksen civarında askeriyle şehir dışına çıkarak, Belh'in suyollarını kesmek için gelen Hüsrev Şah'ın adamlarından, Nazar Bahadır ve adamlarına saldırdı. İki emir arasında meydana gelen mücadelede Emir Tanrıverdi başarılı oldu. ${ }^{106}$ Nazar Bahadır, Hüsrev Şah'ın ordugâhına geri çekildi. Emir Tanrıverdi, Nazar Bahadır'ı izledi ve ona yetişti. Nazar Bahadır, kılıcını çıkardı ve ona saldırdı. Tanrıverdi, kalkanıyla onun kılııını engelledi, onu atından yere düşürdü ve öldürdü. Daha sonra muzaffer bir şekilde kaleye döndü. Bu zafer ile Belh ahalisi cesaretlenmişti. İbrahim Hüseyin Mirza, Tanrıverdi'yi bu başarısından dolayı ödüllendirdi. Sultan Hüseyin Baykara Merv'de

\footnotetext{
103 Khwandamir, a.g.e., s. 470.

${ }^{104}$ Babur, a.g.e., ss. 199-200.

${ }^{105}$ Khwandamir, a.g.e., s. 473.

${ }^{106}$ Babur, a.g.e., s. 199.
} 
kendisine karşı isyan etmiş olan çocukları Ebu'l-Muhsin Mirza ve Muhammed Muhsin Mirza meselesi ile uğraştıktan sonra Serahs'a ilerlediğinde Hüsrev Şah'ın isyan ettiği ve Belh'i kuşattığı haberini aldı. Bunun üzerine Muhammed Masum Mirza ile Emir Ömer Bey'i iki bin atlı adamla birlikte Belh'e gönderdi, kendisi de bir grup askerle onların arkasından ilerledi. Hüsrev Şah, Sultan Hüseyin'in ilerlediğini öğrenince hevesi kırıldı ve hızla Kunduz'a doğru gitti. Bu durum Çiçektu'da Muhammed Masum Mirza vasıtasıyla bildirildi. Daha sonra Emir Nasiruddin Ömer Bey'e İbrahim Hüseyin Mirza'ya yardım için Belh'e gitmesi emredildi. Çünkü Muhammed Masum Mirza, Baykara'nın maiyetine dâhil olmuştu. Daha sonra Sultan Baykara ve maiyeti Badgis merasına doğru gitti ve Baba Haki'de ordugâh kurdu. ${ }^{107}$ Bu sırada kısa süre önce Belh'de Siyahiye dergâhındayken yaşanan bir hadise nedeniyle Sultan ibrahim'in maiyetinden ayrılarak, Hüsrev Şah'ın yanına giden Haydar, barış görüşmeleri için Sultan Hüseyin'in huzuruna gönderildi. Haydar, Sultan Hüseyin'in karargâhında Hüsrev Şah'ı Sultan'a karşı savaşmaya teşvik etmekle suçlanarak hapsedildi. Birkaç gün sonra da öldürüldü. ${ }^{108}$

Sultan Mesud bir müddet Sultan Hüseyin'in yanında kaldı, ancak onun aklı fikri ana vatanındaydı. $\mathrm{O}$, büyük bir orduyla Maveraünnehir'e doğru ilerledi. Kunduz'a eriştiğinde Emir Hüsrev Şah tekrar yalan ve hilelere başvurdu, gönderdiği haberlerle ona sadakat ve bağıı̆̆ı̆ı sunuyor ve hakkı olan topraklar için Sultan Mesud'a söz veriyordu. Hüsrev Şah'ın bu yalan haberlerini alan Sultan Mesud, Kunduz'a gitti. Burada Sultan Mesud'un gözlerini kör ettiren Hüsrev Şah, onu az sayıda adamla birlikte Semerkand'a kardeşi Sultan Ali Mirza'nın yanına gönderdi. Ancak Sultan Mesud, Horasan'a döndü ve Şibani Han Horasan'ı işgal edinceye kadar burada kaldı. Sultan Hüseyin, Timurlu soyundan gelen hiç kimsenin bu hale düşmesini istemediği için onu Serahs valisi Bamaş Mirza üzerine gönderdi, Bamaş Mirza onu öldürdü ve daha sonra da Begüm Sultan'la evlendi. ${ }^{109}$ Hüsrev Şah aynı yıl Hisar

${ }^{107}$ Khwandamir, a.g.e., s. 473.

${ }^{108}$ Wilhelm Barthold, "Mîr Ali ŞirNevaî ve Siyasi Hayatı", çev: Caferoğlu, Abdullah, Ülkü Halkevleri Dergisi, 11/62, Ankara 1938, s. 150.

${ }^{109}$ Khwandamir, a.g.e., s. 470.

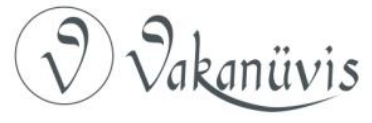


Padişahı ve sözde kendi efendisi olan Baysungur Mirza'yı öldürterek bütün Hisar, Kunduz ve Tirmiz bölgelerinin yegâne hâkimi oldu. ${ }^{110}$

\section{Sonuç}

Timurlu hükümdarı Sultan Ebu Said Han'ın vefatından sonra Ak Koyunlu Uzun Hasan'ın desteğini alan Yadigâr Muhammed hariç, diğer Timurlu mirzalarının Hüseyin Baykara'nın tahtı ele geçiriş sürecinde ciddi bir muhalefet sergilemediklerini görüyoruz. Bu durumun ilk başta Hüseyin Baykara'nın elini rahatlattığını söyleyebiliriz. Ancak Hüseyin Baykara'nın kendi konumunu güçlendirdikten sonra bazı mirzaların gerek ellerindeki toprakları genişletme girişimi ve gerekse Hüseyin Baykara idaresindeki topraklardaki idarecileri isyana teşvik etmeleri ona zarar verdi. Sultan Ebu Said'in vefatından sonra zaten mahalli hanedanlar halini alan devletin durumu, Hüseyin Baykara'nın diğer mirzalarla giriştiği mücadelelerle daha da kötüye gitmiştir. Timurlu devletinin mahalli hanedanlar halini alması devletin gücünü parçaladığı gibi bu mahalli hanedanların ellerindeki gücü birbirlerine karşı kullanmaları devleti içten içe tüketmiştir. Kısacası Ebu Said Han'ın vefatıyla ortaya çıkan durum ve Hüseyin Baykara'nın tahta çıkışıyla mirzaların birbirleriyle olan mücadelesi bize Timurlu devletinin sonunun başlangıcı olduğunu göstermektedir.

Hüseyin Baykara devrinde yaşanan hadiselere baktığımızda bu dönemde devletin dış politikası neredeyse yoktur. Baykara devrinde diğer devletlerle olan ilişkiler, genellikle Akkoyunlu veya Özbek devletlerinin Timurlu devleti üzerindeki emellerinden kaynaklanan ilişkilerden ibarettir. Bize göre bunun sebebi ise yukarıda bahsettiğimiz gibi devletin mahalli hanedanlar halini almış olması ve bu hanedanların birbirleri ile olan mücadeleleriydi. Timurlu devletinin bu dönemde bir dış siyasasının olmayışı, çöküş sürecinin başladığının başka bir delili olduğunu söyleyebiliriz. Hüseyin Baykara'nın Timurlu mirzalarıyla olan mücadelelerini çok geçmeden kendi çocuklarının isyanları nedeniyle onlarla giriştiği mücadeleler izlemiştir. ${ }^{111}$ Dolayısıyla Timurlular, her ne

\footnotetext{
${ }^{110}$ Mirza Haydar Duğlat, Tarih-i Reşidî, İstanbul 2006, s. 333.

${ }^{111}$ Hüseyin Baykara devrinde Timurluların diğer devletlerle ilişkileri hakkında ayrıntılı bilgi için bkz: Cihan Oruç, Hüseyin Baykara ve Zamanı, Basılmamış Yüksek Lisans Tezi, Kütahya 2013.
}

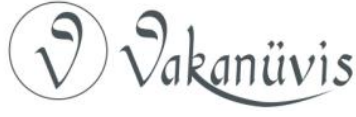


kadar daha sonra tam olarak Şeybani Han'ın saldırıları ile ortadan kalkacak olsa da yıkılışın asıl sebebini dış etkenler yerine bu tür iç etkenlerde aramak doğru olacaktır.

\section{KAYNAKÇA}

Aka, İsmail, "Zünnûn Beg Argûn", İslâm Ansiklopedisi, 13, MEB Yayınları, İstanbul 1986, s. 656-658.

Aka, İsmail, Timur ve Devleti, Ankara 1991.

Alan, Hayrunnisa, "Zünnün Argun", İslam Ansiklopedisi, 44, Türkiye Diyanet Vakfı Yayınları, i̇stanbul 2011, 574-575.

Alan, Hayrunnisa, Sultan Ebu Said Devri Timurlu Tarihi (1451-1469), Basılmamış Doktora Tezi, İstanbul 1996.

Alan, Hayrunnisa, Timurlular 1360-1506, ìstanbul 2007.

Alpargu, Mehmet "Şibani Muhammed Han ve Özbek Hanlığının Yükselişi", Gazi Üniversitesi Gazi Eğitim Fakültesi Dergisi, 8/4, Ankara 1992, 115-142.

Barthold, Wilhelm "Mîr Ali ŞirNevaî ve Siyasi Hayatı", çev: Caferoğlu, Abdullah, Ülkü Halkevleri Dergisi, 10/61, Ankara 1938.

Barthold, Wilhelm "Mîr Ali ŞirNevaî ve Siyasi Hayatı", çev: Caferoğlu, Abdullah, Ülkü Halkevleri Dergisi, 11/62, Ankara 1938.

Beveridge, H. (1988), "Hüseyin Mirza", İlam Ansiklopedisi, 5-1, MEB Yayınları, ìstanbul 1987, 645-646.

Devletşah, Tezkire-i Devletşah, çev: Necati Lügal, İstanbul 1977.

Ebu Bekr-i Tihranî, Kitab-ı Diyarbekriyye, Çev: Mürsel Öztürk, Ankara 2001.

Erşahin, Seyfettin, Akkoyunlular, Ankara 2002.

Gazi Zahireddin Muhammed Babur, Baburnâme, Çev: Prof. Dr. Reşit Rahmeti Arat, i̇stanbul 2005.

Hasan-I Rumlu, Ahsenü't Tevarih, Çev: Mürsel Öztürk, Ankara 2006.

Kemal al-Din 'Abd al-Razzaq Samarqandi, Matla'-i Sa'dayn wa Majma'-i Bahrayn, 2, Haz: Nawâ'i, 'Abd al-Husayn, Tehran 2004.

Khwandemir, Habıbu's-Sıyer, Tome Three, Çev: W. M. Thackston, Harvard 1994.

Kılıç, Remzi "Fatih Devri (1451-1481) Osmanlı-Akkoyunlu ilişkileri", Erciyes Üniversitesi Sosyal Bilimler Enstitüsü Dergisi, 14/94-118, Kayseri 2003.

Mehdi Farhani Monfard, Politics and Culture at the end of the Timurid and early Safavid period (1468-1505), Tehran 2003.

Mirhand, Ravzatu's Safa, 7, Tehran 1229 (h. ş.)

Mirza Haydar Duğlat, Tarih-i Reşidî, İstanbul 2006.

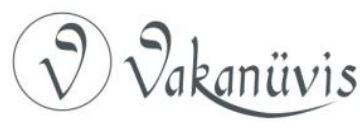


Muinüddin Muhammed el-İsfizari, Ravzatü'l cennet fi evsaf-i medineti'l Herat, Tehran 1338 (h. ş)

Oruç, Cihan, Hüseyin Baykara ve Zamanı, Basılmamış Yüksek Lisans Tezi, Kütahya 2013.

Roux, Jean Paul, Orta Asya Tarih ve Uygarlık, Çev: Lale Arslan, İstanbul 2006.

Yıldırım, Talip, Hüseyin Baykara Divanı, İstanbul 2010. 